\title{
HUBUNGAN MOTIVASI ORANGTUA UNTUK MENCAPAI KESEMBUHAN ANAK DENGAN TINGKAT PENGETAHUAN TENTANG PENANGANAN ANAK PENYANDANG AUTISME DAN SPEKTRUMNYA
}

\section{THE RELATION BETWEEN PARENT'S MOTIVATION TO REACH THE CHILDREN'S HEALING PROCESS AND PARENT'S KNOWLEDGE ABOUT THE TREATMENT OF CHILDREN WITH AUTISM SPECTRUM DISORDER}

\author{
Asmika * , Sri Andarini *, Ririn Puji Rahayu** \\ * Laboratorium Imu Kesehatan Masyarakat Fakultas Kedokteran Universitas Brawijaya Malang \\ ${ }^{* *}$ Program Studi Pendidikan Dokter Fakultas Kedokteran Universitas Brawijaya Malang
}

\begin{abstract}
The incidence of children with autisme spectrum disorder has rapidly increased, starting fom 1:1500 in 1987 to1:100 in year 2001. The parent's motivation for actively being involved in treatment programs, such as consultation with the expert and improvement of their knowledge will increase the treatment success up to $80 \%$. Therefore it is of paramount importance to identify the parent's motivation and knowledge about Autisme treatment as a baseline for improving parent's active involvement. A cross sectional research design was carried out using twenty parents (mother/father or both) as responden is in Autisme treatment center: A-Plus' Dharma Wanita PUNM Malang District from15 April - 31 May 2003. The parents motivation and knowledge level was measured using close ended questionnaire. In general, autisme is mostly identified in male child (55\%), first child (45\%)and diagnosed by children specialist or psychiatrist (75\%) at the age of 0-2 year (75\%). Most of the parents (85\%) have a high motivation in gaining children healing but $60 \%$ parents have low knowledge level about Autisme treatment with mass media as the main information source (85\%). There is no significant relationship $(p>0,05)$ between parent's motivation and knowledge level.
\end{abstract}

Key Words: motivasi, pengetahuan orang tua, Autisme dan spektrumnya

\section{PENDAHULUAN}

Memiliki anak sehat jasmani dan rohani adalah harapan para orangtua. Harapan ini menyangkut pertumbuhan dan perkembangan yang paling optimal dari segi fisis, emosi, mental dan sosial setiap anak (1). Harapan tersebut tidak mudah terpenuhi jika anak mengalami gangguan perkembangan pervasif diantaranyan Autisme dan spektrumnya selanjutnya disebut sebagai Autisme $(2,3)$. Autisme pada anak menyebabkan anak tidak mampu mengadakan interaksi sosial dan seolah hidup dalam dunianya sendiri (4).

Jumlah anak penyandang Autisme di Indonesia terjadi peningkatan yang drastis. Penelitian pada tahun 1987 menunjukkan bahwa bahwa penderita Autisme 1:5000. Sepuluh tahun kemudian tahun 1997 penderita Autisme 1:500. Tahun 2000 penderita Autisme 1:150. Terakhir tahun 2001 menunjukkan penderita Autisme 1:100 $(5,6)$.

Penanganan Autisme disamping oleh tenaga kesehatan juga menuntut peran orang tua. Beberapa ahli

Jurnal Kedokteran Brawijaya, Vol. XXII, No.2, Agustus 2006

Korespondensi: Asmika; Laboratorium IImu Kesehatan Masyarakat, Fakultas Kedokteran Unibraw; JI. Veteran Malang 65145; Telp. (0341) 569117 mengatakan peran aktif orangtua dalam usaha membantu anak menjalankan terapi merupakan salah satu faktor penting karena tanpa dukungan orangtua proses untuk mencapai kesembuhan akan berjalan lebih lama $(7,8)$. Keadaan ini mendorong orang tua untuk berkomunikasi dengan para ahli dan memperdalam pengetahuannya, karena dapat berdampak terhadap keberhasilan terapi anak sampai dengan $80 \%$ (9).

Orangtua anak penyandang Autisme perlu untuk selalu mencari informasi terbaru (up to date) dan memperdalam ilmu mengenai Gangguan Perkembangan Pervasif melalui beberapa 2 metode. Metode yang pertama adalah mengikuti atau mencari training untuk para orangtua (parent training) dari para profesional. Disamping itu dapat dilakukan dengan mencari support untuk orangtua dengan membentuk sharing group atau support group diantara orangtua sehingga dapat saling berbagi informasi dan support (8).

Meskipun orang tua dituntut berperan aktif namun pengetahuan orang tua tentang Autisme masih minim. Berdasarkan survey pendahuluan di Pusat Terapi 'A-Plus' Malang, $90 \%$ orangtua pada awalnya tidak mengetahui tentang Autisme hingga anak mereka didiagnosa menyandang Autisme. Dari hasil wawancara dengan salah satu anggota HOPA (Himpunan Orangtua Peduli Autisme) 
Malang, pada tahapan lanjutan HOPA telah melaksanakan suatu kegiatan yang diharapkan dapat menambah pengetahuan orangtua tentang Autisme dan Spektrumnya tetapi pada kenyataannya masih ada beberapa orangtua masih memiliki pengetahuan yang kurang.

Masih rendahnya pengetahuan orang tua dapat disebabkan motivasi orang tua untuk mencapai kesembuhan anak dan tingkat kesadaran akan peran aktif orangtua. Motivasi untuk mencapai kesembuhan yang diiringi dengan kesadaran akan pentingnya peran aktif akan mendorong orang tua untuk meningkatkan pengetahuan. Karena itu menarik untuk dikaji hubungan motivasi orang tua untuk kesembuhan anak dengan tingkat pengetahuannya tentang penanganan anak penyandang Autisme.

\section{METODE}

Penelitian dilakukan dengan pendekatan cross sectional study dengan sampel dalam penelitian ini adalah semua orang tua (ayah atau ibu atau keduanya) dari anak penyandang Autisme yang diterapi di Pusat Terapi 'A-Plus' Dharma Wanita PUNM Kotamadya Malang sebanyak 20 responden.. Instrumen yang digunakan adalah kueisioner tertutup dan terbuka dengan tehnik wawancara.

Cara pengukuran motivasi dengan teknik Scorring skala Likert (10). Responden diminta untuk memberikan jawaban sangat setuju (SS), setuju (S), ragu-ragu (RR), tidak setuju (TS) dan sangat tidak setuju (STS). Dengan pemberian skor 1 (sangat tidak setuju) sampai 5 (sangat setuju). Pengukuran pengetahuan dilakukan dengan memberikan skor pada setiap jawaban responden sesuai dengan tingkat kebenaran pilihan jawaban. Skor maksimal ditetapkan sesuai dengan jumlah pilihan jawaban dengan bobot yang sama.

Total skor pengetahuan dan motivasi selanjutnya dikategorikan dengan kriteria berikut:

\begin{tabular}{ccc}
\hline HAL & SKOR/NILAI & KETERANGAN \\
\hline Motivasi & $20-34$ & Tinggi \\
& $0-19$ & Rendah \\
Pengetahuan & $17-31$ & Tinggi \\
& $0-16$ & Rendah \\
\hline
\end{tabular}

Karakteristik responden dan anak penyandang Autisme diolah secara deskriptif dengan menggunakan proporsi, sedangkan hubungan antara tingkat motivasi dan kesembuhan dianalisa dengan uji statistik Fisher menggunakan program SPSS (Statistical Product and Service Solution) for MS Windows Release 10,0.

\section{HASIL PENELITIAN}

Data yang dikaji dalam penelitian ini meliputi karakteristik orang tua, karakteristik anak Autisme, sumber informasi serta tingkat pengetahuan dan motivasi. Orang tua laki-laki terbanyak berusia $>35$ tahun $(45 \%)$ sebaliknya ibu terbanyak berusia $<35$ tahun. Status sosial eknomi orang tua sebagian besar berada pada golongan menengah dengan tingkat pendidikan perguruan tinggi (70\%), penghasilan per bulan $>$ Rp. $2000.000,00$, pekerjaan wiraswasta $(60 \%)$ untuk bapak dan ibu tidak bekerja $(40 \%)$ dan memiliki anaklebih dari 1 (85\%).

\section{Karakteristik Anak Penyandang Autisme}

Tabel1. Sebaran Anak Penyandang Autisme Berdasarkan Urutan Anak, Jenis Kelamin, Usia Didiagnosis dan Pelaku Diagnosis.

\begin{tabular}{lcc}
\hline \multicolumn{1}{c}{ Karakteristik } & Jumlah & $\%$ \\
\hline Urutan anak Autisme & & \\
a. 1 & 9 & 45 \\
b. 2 & 8 & 40 \\
c. >2 & 3 & 15 \\
Jenis kelamin anak Autisme & & \\
a. laki-laki & 15 & 75 \\
b. perempuan & 5 & 25 \\
Usia didiagnosa Autisme & & \\
a. 0-2 tahun & 11 & 55 \\
b. 2,1-4 tahun & 5 & 25 \\
c. 4,1-6 tahun & 2 & 10 \\
d. $\quad 6,1-8$ tahun & 1 & 5 \\
e. >8 tahun & - & 0 \\
f. Abstain & 1 & 5 \\
Diagnosa/dinyatakan anak & & \\
Autisme oleh: & & \\
a. dokter umum & - & 0 \\
b. dokter spesialis & 15 & 75 \\
$\quad$ anak/psikiater & & \\
c. psikolog & 5 & 25 \\
d. tahu sendiri & 1 & 5 \\
e. abstain & 1 & 5 \\
\hline
\end{tabular}

Karakteristik anak penyandang Autisme pada Tabel 1 menunjukkan distribusi terbesar penyandang Autisme adalah anak pertama (45\%), laki-laki(75\%) terdiagnosa pada usia 0-2 tahun (55\%) oleh dokter spesialis anak/psikiater (75\%).

Media cetak (85\%)dan elektronika (55\%) merupakan sumber informasi yang dominan bagi orang tua, sedangkan tenaga kesehatan berada pada urutan ketiga (45\%).

Secara umum proporsi orangtua penyandang Autisme yang memiliki tingkat pengetahuan rendah lebih besar $(60 \%)$ dibandingkan yang tinggi (Tabel 3$)$. Secara khusus tidak semua gejala Autisme dan jenis terapi diketahui oleh responden, sedangkan diet pada anak Autisme diketahui oeh semua responden. Terlambat bicara, tidak mau menatap lawan bicara dan tidak memahami pembicaraan orang lain merupakan tiga gejala yang diketahui oleh hampir semua responden (80\%-95\%). Gejala Autisme berupa rasa takut yang tidak wajar dan komunikasi 
dengan gerakan tubuh hanya diketahui oleh 40\%-50\% responden, sedangkan semua responden mengetahui tentang diet dan yang mengetahui kelima gejala hanya 15\%. Terapi medikamentosa dan perilaku merupakan dua jenis terapi yang banyak diketahui responden (75\%-90\%), terapi seni dan konseling diketahui oleh 35\%-45\% reponden sedangkan terapi musik hanya diketahui $5 \%$ responden.

\section{Sumber Informasi tentang Autisme}

Tabel 2. Distribusi Sumber Informasi Responden tentang Autisme

\begin{tabular}{lcc}
\hline \multicolumn{1}{c}{ Sumber Informasi } & Jumlah & $\%$ \\
\hline a. Tenaga kesehatan & 9 & 45 \\
b. Orang umum & 2 & 10 \\
c. Media cetak (majalah, surat kabar, buku, dll) & 17 & 85 \\
d. Media elektronika & 11 & 55 \\
e. lain-lain & 4 & 20 \\
\hline
\end{tabular}

\section{Pengetahuan Responden}

Tabel 3. Sebaran Pengetahuan Responden tentang Gejala, Deteksi Dini dan Penanganan Autisme beserta Spektrumnya

\section{Gejala Autisme}

a. Terlambat bicara

b. Komunikasi dengan gerakan tubuh

c. Tidak mau menatap mata lawan bicara

d. Tidak memahami pembicaraan orang lain

e. Rasa takut yang tidak wajar

f. Yang menjawab kelima gejala Autisme Jenis Terapi

a. Terapi medikamentosa (obat-obatan)

b. Terapi perilaku

c. Terapi musik

d. Terapi seni lainnya

e. Konseling/konsultasi

f. Yang menjawab kelimanya

Diet Anak Autisme

- Tahu

- Tidak Tahu

Penanganan Anak Autisme

- Pengetahuan tinggi

- Pengetahuan rendah

\section{Jumlah}

$\%$

$\begin{array}{cc}19 & 95 \\ 8 & 40 \\ 19 & 95 \\ 16 & 80 \\ 10 & 50 \\ 3 & 15 \\ 15 & \\ 18 & 75 \\ 9 & 90 \\ 1 & 45 \\ 7 & 5 \\ 1 & 35 \\ & 5 \\ 20 & \\ - & 100 \\ 8 & 0 \\ 16 & \\ & \\ & 40 \\ & 60\end{array}$

\section{Motivasi Orangtua untuk Kesembuhan Anak Penyandang Autisme}

Tabel 4. Tingkat Motivasi Orangtua untuk Mencapai Kesembuhan Anak Penyandang Autisme

\begin{tabular}{lcc}
\hline \multicolumn{1}{c}{ Tingkat Motivasi } & Jumlah & $\%$ \\
\hline Motivasi tinggi & 17 & 85 \\
Motivasi rendah & 5 & 15 \\
\hline
\end{tabular}

Gambaran proporsi tingkat motivasi (Tabel 4) responden berbanding terbalik dengan tingkat pengetahuan (Tabel 3). Sebagian besar orang tua (85\%) mempunyai tingkat motivasi tinggi untuk mencapai kesembuhan anak.

Hasil uji statistik Fisher Exact dengan tingkat kepercayaan 95\% diperoleh $p$-value 0,6561404 ( $p>0,05)$, yang menunjukkan tidak ada hubungan yang bermakna antara motivasi orangtua untuk mencapai kesembuhan anak dengan tingkat pengetahuan tentang penanganan anak penyandang Autisme dan Spektrumnya. 
Hubungan Motivasi dengan Pengetahuan

Tabel 5. Hubungan antara Tingkat Motivasi dan Pengetahuan responden

\begin{tabular}{|c|c|c|c|c|c|}
\hline \multirow{3}{*}{ Motivasi } & \multicolumn{3}{|c|}{ Tingkat Pengetahuan } & \multirow{3}{*}{ Value } & \multirow{3}{*}{ Kemaknaan } \\
\hline & Tinggi & \multicolumn{2}{|c|}{ Rendah } & & \\
\hline & $\mathrm{Jml} \mathrm{a}$ & Jml & $\%$ & & \\
\hline Tinggi & 73 & 10 & 50 & & $p>0.05$ \\
\hline Rendah & 1 & 2 & 10 & & \\
\hline
\end{tabular}

DISKUSI

Usia ibu dan jumlah anak dalam keluarga mempengaruhi terjadinya Autisme dan penanganannya. Tiga puluh lima persen ibu berusia $>35$ tahun. Hal ini sesuai dengan data statistik yang didukung penjelasan biologis bahwa, usia ibu $>35$ tahun merupakan usia yang berisiko tinggi terhadap terjadinya gangguan kehamilan maupun persalinan. Semakin tinggi usia ibu saat hamil kemungkinan bayinya mengalami Autisme semakin besar. Kelainan yang mungkin terjadi adalah perdarahan pada trimester I dan II, kasus bayi premature, post date, perinatal anoksia maupun komplikasi persalinan lainnya seperti partus kasep, infeksi jalan lahir dan lain-lain (11). Sebagian besar responden mempunyai anak $>1$ (85\%) yang dapat mempengaruhi besarnya perhatian yang diberikan oleh orangtua kepada anak dan kemampuan keuangan keluarga untuk membiayai pengobatan.

Gambaran urutan anak dan usia penyandang Autisme pada penelitian ini sesuai dengan penelitian lain. Distribusi terbesar penyandang Autisme adalah anak pertama (45\%) sesuai dengan teori bahwa anak pertama lebih berpotensi terkena Autisme. Sebagian besar (75\%) anak penyandang Autisme adalah laki-laki, hal ini sesuai dengan data statistik yang ada bahwa perbandingan penyandang Autisme laki-laki:perempuan adalah 4:1 $(6,7)$.

Dari Tabel 1, diketahui bahwa $55 \%$ anak penyandang Autisme didiagnosa pada usia 0-2 tahun, karena pada usia tersebut secara umum anak seharusnya sudah mampu berkomunikasi, sehingga orang tua mudah curiga bila menemukan kelambatan perkembangan komunikasi. Gangguan perkembangan anak yang dapat menimbulkan kecurigaan atau deteksi dini gangguan Autisme misalnya ketika anak tidak mau menatap lawan bicara, tidak respon dengan panggilan, tidak dapat bicara, melakukan gerakan tertentu yang berulang-ulang maupun kurang atau tidak memiliki imajnasi yang cukup dalam bermain.

Sebagian besar $(75 \%)$ diagnosa Autisme pertama kali oleh dokter spesialis anak maupun psikiater. Hal ini menunjukan bahwa dokter masih merupakan tumpuan masyarakat untuk menghadapi kasus gangguan kesehatan maupun tumbuh kembang dan kejiwaan anak, walaupun hanya $45 \%$ responden mengaku mendapatkan informasi tentang Autisme dari tenaga kesehatan. Media cetak (majalah, surat kabar, buletin, buku, dII) merupakan sumber informasi terbesar $(85 \%)$ tentang Autisme yang diperoleh responden. Hal ini dapat disebabkan karena seiring dengan meningkatnya angka kejadian Autisme diikuti oleh maraknya pembahasan tentang Autisme di media cetak maupun seminar.

Autisme merupakan spectrum disorder yaitu gangguan kesehatan dengan banyak variasi gejala, dari samar sampai sangat jelas. Hal ini dapat disebabkan perbedaan kelainan dalam otak. Oleh karena itu dua anak penyandang Autisme dapat menunjukkan gejala yang sangat berbeda sehingga terapinya juga berbeda. Besarnya variasi gejala Autisme antar penyandang yang menyebabkan rendahnya proporsi orang tua yang mengetahui kelima gejala Autisme (5\%). Sedangkan dua gejala utama dan juga sering dibahas dalam berbagai media (terlambat bicara, tidak mau menatap lawan saat bicara) banyak diketahui orang tua. Gambaran ini dapat menyebabkan tidak terdeteksinya Autisme dengan gejala yang tidak khas oleh orang tua.

Terapi perilaku merupakan terapi yang banyak $(90 \%)$ diketahui orang tua. Terapi perilaku bagi anak penyandang Autisme sangat diperlukan untuk mencapai habilitasi anak sehingga anak mampu berfungsi seperti anak normal. Proporsi jenis terapi yang diketahui responden secara tidak langsung menggambarkan jenis terapi yang dilakukan pada anak penyandang Autisme. Rendahnya proporsi orang tua yang mengetahui terapi konseling dan konsultasi (35\%) dibandingkan jenis terapi lain secara tidak langsung menggambarkan kurangnya partisipasi orang tua dalam meningkatkan pengetahuan dan keterlibatan dalam penyembuhan anak.

Seluruh responden (100\%) mengetahui bahwa anak penyandang Autisme memerlukan diet khusus. Hal ini menunjukkan telah meluasnya informasi diet sebagia bagian dari penanganan Autisme. Diet pada anak Autisme pada umumnya adalah GFCF (Glutein Free Cassein Free) tetapi tiap-tiap anak mempunyai pola diet yang berbedabeda sesuai dengan hasil tes biomedikasi anak tersebut.

Hasil analisis menunjukkan bahwa tingginya motivasi untuk mencapai kesembuhan tidak selalu diikuti peningkatan pengetahuan tentang penanganan Autisme. Hal ini dapat disebabkan rendahnya proporsi orang tua yang mengetahui konseling dan konsultasi sebagai bentuk terapi sekaligus sumber informasi.

Disamping itu jenis terapi yang banyak diketahui responden adalah jenis terapi yang dominan dilakukan oleh tenaga medis. Artinya sebagian besar orang tua tidak banyak mengetahui bentuk terapi yang melibatkan partisipasi orang tua, sehingga tidak merasa penting untuk meningkatkan pengetahuan. Oleh karena itu meskipun 
orang tua memiliki motivasi yang tinggi untuk kesembuhan anak tidak otomatis diikuti dengan keinginan untuk meningkatkan pengetahuan tentang autisme.

Bentuk keterlibatan orang tua lebih pada kemampuan untuk membiayai berbagai terapi. Penyebab lain adalah adanya hambatan aktivitas mencari informasi tentang Autisme, misalnya faktor kesibukan, faktor dana yang terbatas atau sumber informasi tentang Autisme yang kurang memadai. Pentingnya updating pengetahuan orang tua tentang penanganan autisme bukan hanya karena terapi autisme banyak melibatkan orang tua tetapi juga masih berkembangnya berbagai model teori dan penelitian tentang terapi Autisme.

\section{KESIMPULAN DAN SARAN}

Autisme banyak ditemukan pada anak lelaki, anak pertama dan terdiagnosis oleh dokter spesialis anak atau psikiater pada usia 0-2 tahun. Sebagian besar orang tua memiliki motivasi tinggi untuk mencapai kesembuhan yang tinggi meskipun sebagian besar memiliki tingkat pengetahuan rendah dengan media masa sebagai sumber informasi utama. Tingginya motivasi orang tua untuk mencapai kesembuhan anak tidak berhubungan dengan tingkat pengetahuan tentang penanganan autisme. Hal ini dapat disebabkan tidak diketahuinya berbagai bentuk terapi yang banyak membutuhkan peran aktif orang tua, sehingga orang tua menyerahkan proses penyembuhan kepada ahlinya.

Orangtua dari anak penyandang Autisme dan masyarakat umum perlu meningkatkan pengetahuan tentang deteksi dini dan penanganan anak Autisme melalui training dan sharring group diantara orangtua. Pusat terapi dan tenaga kesehatan perlu meningkatkan kegiatankegiatan konseling, penyuluhan, seminar dan sejenisnya serta mengadakan training khusus untuk para orangtua.

\section{DAFTAR KEPUSTAKAAN}

1. Hasan R, Alatas H. Buku Kuliah "Ilmu Kesehatan Anak". Bagian IImu Kesehatan Anak. Fakultas Kedokteran Universitas Indonesia. Jakarta; 1985; Edisi (1) : 65.

2. Hersey P, Blanchard K. Motivasi dan Perilaku Organisasi. Diterjemahkan oleh Agus Dharma. Jakarta: Erlangga; 1986:16.

3. Yuniar S. Gangguan Spektrum Autisme dan Kiat Menanggulanginya. Makalah disajikan dalam Seminar Mempersiapkan Anak Penyandang Autisme Hidup Mandiri. Malang, 6 April 2003.

4. Humphries J, Muggleton J. Autism: Recognising The Signs In Young Children. (online), http://eee.mugsy.org/pmth [accessed 31 May 2002]

5. Soelaeman R. Menangani Anak Autis. Jakarta: Gramedia: Nakita; Edisi Februari 2002: 5-11,13-15, 42-44, 61-62.

6. Widyawati I. Aspek Psikiatrik pada Autisme. Makalah disajikan dalam Seminar Autisme, Yayasan Autisme Indonesia. Jakarta; 30 Agustus 1997

7. Anonymus.Terapi dan Pendidikan bagi Anak dengan Gangguan Pervasif. (online) 2001 http://www.spectrumauti.com/i, pervasif2.htm [ accesed 31 March 2002].

8. Sardiman AM. Interaksi dan Motivasi Belajar Mengajar. Jakarta; Rajawali Pers; 1998: 78.

9. Chandra T. Membantu Orangtua dalam Menangani dan Mendidik Anak dengan Gangguan Perkembangan Pervafif, (Online) 2002 http://www.spectrum-auti.com/i, pervasif2.htm, [ accesed 19 March 2002]

10. Whalizer MH, Eienir PL. Metode dan Analisis Penelitian. Mencari Hubungan. Jilid I. Diterjemahkan oleh Sadiman AS, Hutagaol S. Jakarta: Erlangga; 1986; 96.

11. Kaplan HL, Sadock BI, Grebb JA, Williams and Wilkins. Gangguan Perkembangan Pervasif. Sinopsis Psikiatri: IImu Pengetahuan Perilaku Psikiatri Klinis.1996, Edisi (7). Diterjemahkan oleh Wijaya Kusuma, Jakarta : Bina Rupa Aksara; $1997: 715$. 